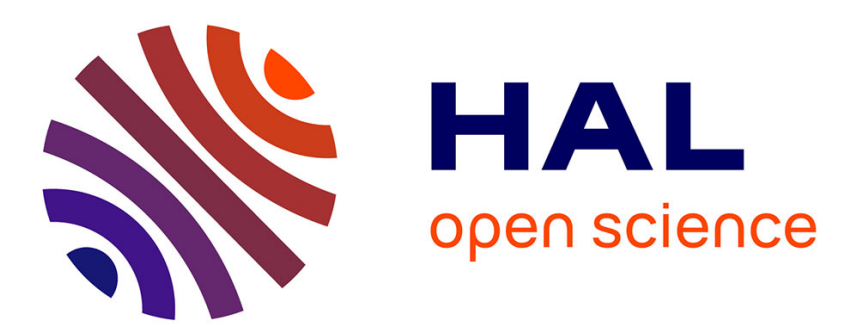

\title{
Agglutinated tubes as a feature of Early Ordovician ecosystems
}

Lucy A. Muir, Joseph P. Botting, Bertrand Lefebvre, Christopher Upton, Yuan-Dong Zhang

\section{To cite this version:}

Lucy A. Muir, Joseph P. Botting, Bertrand Lefebvre, Christopher Upton, Yuan-Dong Zhang. Agglutinated tubes as a feature of Early Ordovician ecosystems. Paleoworld, 2019, 28 (1-2), pp.96-109. 10.1016/j.palwor.2019.01.004 . hal-03004894

\section{HAL Id: hal-03004894 https://hal.science/hal-03004894}

Submitted on 13 Nov 2020

HAL is a multi-disciplinary open access archive for the deposit and dissemination of scientific research documents, whether they are published or not. The documents may come from teaching and research institutions in France or abroad, or from public or private research centers.
L'archive ouverte pluridisciplinaire HAL, est destinée au dépôt et à la diffusion de documents scientifiques de niveau recherche, publiés ou non, émanant des établissements d'enseignement et de recherche français ou étrangers, des laboratoires publics ou privés. 


\section{Manuscript Details}

\section{Manuscript number}

Title

Article type
PALWOR_2018_48_R1

Agglutinated tubes as a feature of Early Ordovician ecosystems

\section{Abstract}

Agglutinated tubes are produced by a variety of marine organisms. Such tubes will readily break down after the death of the producer, and hence are likely to be found only in deposits with rapid burial and/or exceptional preservation. Here we document agglutinated tubes from four localities of Early Ordovician age. The Lower Ordovician (upper Tremadocian) Afon Gam Biota of North Wales, UK, contains a diverse fossil assemblage including algae, worms, sponges, hyoliths, tergomyans, echinoderms, trilobites, and other arthropods. The biota also includes locally abundant agglutinated tubes composed largely of echinoderm fragments, in particular glyptocystitid (including Macrocystella) stem and brachiole ossicles. The tube producer appears to have preferentially selected echinoderms for use in tube building, with trilobites and tergomyans only rarely incorporated in the tubes. These tubes are named Echinokleptus anileis gen. et sp. nov. Similar tubes, although incorporating individual echinoderm ossicles rather than complete animals, occur in the Lower Ordovician (lower Floian) Tonggao Formation of South China. Possible additional agglutinated tubes are found in the Tremadocian-Floian Fezouata Shale of Morocco; these examples are composed of a range of bioclasts including echinoderm remains and hyolithids. Further possible tubes composed of mixed shelly material were observed in the Floian Landeyran Formation, Montagne Noire, France. The occurrence of morphologically similar agglutinated tubes on different continental blocks and at different palaeolatitudes indicates that the group responsible (inferred to be a polychaete annelid) was diversifying as part of the Great Ordovician Biodiversification Event, and similar interpretations should be considered for problematic bioclastic accumulations elsewhere.

\section{Keywords}

Corresponding Author

Order of Authors

Suggested reviewers agglutination, Annelida, Ordovician Radiation, Polychaeta

Lucy Muir

Lucy Muir, Joseph Botting, Bertrand Lefebvre, Christopher Upton, Yuan-Dong Zhang

Mark Wilson, Michal Zaton, Olev Vinn 


\section{Submission Files Included in this PDF}

\section{File Name [File Type]}

muir et al covering letter revised.docx [Cover Letter]

muir et al response to reviewers.docx [Response to Reviewers]

Muir et al title page revised.docx [Title Page (with Author Details)]

Muir et al Ordovician agglutinated tubes REVISED.docx [Manuscript File]

Muir et al Figure 1.tif [Figure]

Muir et al Figure 2.tif [Figure]

Muir et al Figure 3 colour.tif [Figure]

Muir et al Figure 3 greyscale.tif [Figure]

Muir et al Figure 4 colour.tif [Figure]

Muir et al Figure 4 greyscale.tif [Figure]

muir et al figure 5 colour.tif [Figure]

muir et al figure 5 greyscale.tif [Figure]

muir et al figure 6 colour.jpg [Figure]

muir et al figure 6 greyscale.jpg [Figure]

Muir et al Figure 7 greyscale.tif [Figure]

Muir et al Figure 7 colour.tif [Figure]

Muir et al Figure 8.tif [Figure]

muir et al Table 1.docx [Table]

To view all the submission files, including those not included in the PDF, click on the manuscript title on your EVISE Homepage, then click 'Download zip file'. 


\section{Agglutinated tubes as a feature of Early Ordovician ecosystems}

Lucy A. MUIR ${ }^{1 *}$, Joseph P. BOTTING ${ }^{1,2}$, Bertrand LEFEBVRE ${ }^{3}$, Christopher UPTON ${ }^{4}$, Yuandong ZHANG

1. Department of Natural Sciences, Amgueddfa Cymru - National Museum Wales, Cathays Park, CardiffCF10 3LP, UK, lucy@asoldasthehills.org, acutipuerilis@yahoo.co.uk

2. Nanjing Institute of Geology and Palaeontology, 39 East Beijing Road, Nanjing 210008, China

3. UMR CNRS 5276 LGLTPE, Université Lyon 1, 2 rue Raphaël Dubois, 69622 Villeurbanne cedex, France. bertrand.lefebvre@univ-lyon1.fr

4. 1 Hamilton Terrace, Shoscombe, Bath BA2 8ND, UK, chrischris.upton@gmail.com

5. CAS Key Laboratory of Economic Geology and Stratigraphy, Nanjing Institute of Geology and Palaeontology and Center for Excellence in Life and Palaeoenvironment, Chinese Academy of Sciences, 39 East Beijing Road, Nanjing 210008, China, ydzhang@nigpas.ac.cn *Corresponding author 
1 Agglutinated tubes as a feature of Early Ordovician ecosystems

3 Lucy A. MUIR ${ }^{1 *}$, Joseph P. BOTTING ${ }^{1,2}$, Bertrand LEFEBVRE ${ }^{3}$, Christopher UPTON ${ }^{4}$, $4 \quad$ Yuandong $Z H A N G^{5}$

5 1. Department of Natural Sciences, Amgueddfa Cymru - National Museum Wales, Cathays

6 Park, CardiffCF10 3LP, UK, lucy@asoldasthehills.org, acutipuerilis@yahoo.co.uk

7 2. Nanjing Institute of Geology and Palaeontology, 39 East Beijing Road, Nanjing 210008,

8 China

9 3. UMR CNRS 5276 LGLTPE, Université Lyon 1, 2 rue Raphaël Dubois, 69622 Villeurbanne cedex, France. bertrand.lefebvre@univ-lyon1.fr

4.1 Hamilton Terrace, Shoscombe,BathBA2 8ND, UK, chrischris.upton@gmail.com

5. CAS Key Laboratory of Economic Geology and Stratigraphy, Nanjing Institute of Geology and Palaeontology and Center for Excellence in Life and Palaeoenvironment, Chinese Academy of Sciences, 39 East Beijing Road, Nanjing 210008, China, ydzhang@nigpas.ac.cn *Corresponding author

\section{Abstract}

Agglutinated tubes are produced by a variety of marine organisms. Such tubes will readily break down after the death of the producer, and hence are likely to be found only in deposits with rapid burial and/or exceptional preservation. Here we document agglutinated tubes from four localities of Early Ordovician age. The Lower Ordovician (upper Tremadocian) Afon Gam Biota of North Wales, UK, contains a diverse fossil assemblage including algae, worms, sponges, hyoliths, tergomyans, echinoderms, trilobites, and other arthropods. The biota also includes locally abundant agglutinated tubes composed largely of echinoderm fragments, in particular glyptocystitid (including Macrocystella) stem and brachiole ossicles. The tube producer appears to have preferentially selected echinoderms for use in tube building, with trilobites and tergomyans only rarely incorporated in the tubes. These tubes are named Echinokleptus anileis gen. et sp. nov. Similar tubes, although incorporating individual echinoderm ossicles rather than complete animals, occur in the Lower Ordovician (lower Floian) Tonggao Formation of South China. Possible additional agglutinated tubes are found in the Tremadocian-Floian Fezouata Shale of Morocco; these examples are composed of a range of bioclasts including echinoderm remains and hyolithids. Further possible tubes composed of mixed shelly material were observed in the Floian Landeyran Formation, Montagne Noire, France. The occurrence of morphologically similar agglutinated tubes on 
different continental blocks and at different palaeolatitudes indicates that the group responsible (inferred to be a polychaete annelid) was diversifying as part of the Great Ordovician Biodiversification Event, and similar interpretations should be considered for problematic bioclastic accumulations elsewhere.

Keywords: agglutination, Annelida, Ordovician Radiation, Polychaeta

\section{Introduction}

Agglutinated tubes are constructed by a diverse range of animal and protistan groups in marine, freshwater and terrestrial environments. Among insects, caddis-fly larvae (order Trichoptera) are a well-known freshwater example, and the bagworm moths (Psychidae) are terrestrial equivalents. In the marine realm, extant taxa known to build agglutinated dwelling structures, within the sediment of the sea bed and/or extending above the sediment surface, include foraminifera (e.g. Gooday et al., 1992; Miller, 2005), polychaete annelids (e.g. Myers, 1972), sea anemones (e.g. Frey, 1970) and crustaceans (e.g. Hassack and Holdich, 1987). However, these tubes are relatively rare in the fossil record; this is due to their low preservation potential, as they often fall apart shortly after the death of the animal (Finger et al., 2008). Thus, rapid burial and weak hydrodynamic intensity are necessary for their preservation and they are most commonly encountered in Konservat-Lagerstätten or other deposits with some degree of exceptional preservation.

Despite their fragility, agglutinated tubes can be important components of marine communities, affecting the ecosystem by stabilising (e.g. Bailey-Brock, 1984) or destabilising (e.g. Eckman et al., 1981) the sediment, or by providing a habitat for other organisms to grow on (e.g. Lipps and Ronan, 1974; Gooday et al., 1992; Langer and Long, 1994) or inhabit (e.g. Gooday, 1984; Bell, 1985; Gherardi and Cassidy, 1995). They can even be reef-forming if present in sufficient abundance (e.g. Kirtley and Tanner, 1968; Fischer et al., 1989; Burke et al., 1992; Ekdale and Lewis, 1993; Naylor and Viles, 2000).

Agglutinated tubes are known in the fossil record from the Cambrian onwards (e.g. Lipps and Sylvester, 1968; Ettensohn, 1981; Signor and McMenamin, 1988; Hannah and Collen, 1995; Miller, 2005; Vinn and Luque, 2013; Muir et al., in press). Many of the described tubes are thought to be the work of foraminifera (e.g. Miller, 2005) or polychaete annelids (e.g. de Gilbert, 1996; Zatoń et al., 2012; Vinn and Luque, 2013; Zatoń and Bond, 2016). Tubes or agglutinated burrow linings (which can be difficult to separate in the fossil record) ascribed to 
organisms other than polychaetes and foraminifera have also been described, such as the Jurassic possible coelenterate burrow Kulindrichnus (Hallam, 1960). A variety of nonagglutinated, generally organic, burrow linings or tubes probably produced by polychaete worms are also known from the fossil record (e.g. Thomas and Smith, 1998). These structures are structurally distinct from the specimens described in this paper, and will not be considered further.

The studied localities preserve biotas from the early part of the Great Ordovician Biodiversification Event (GOBE; Harper, 2006; Servais et al., 2010), which is also called the Ordovician Radiation. One of the major unanswered questions about the Ordovician Radiation is how it affected taxa with a low preservation potential, such as polychaete worms, because of the small number of Konservat-Lagerstätten known from the Ordovician (Muscente et al., 2017). Evidence from aspects such as trace fossils (Mángano and Droser, 2004) and agglutinated tubes is therefore important in assessing the history of soft-bodied animals during this interval.

\section{Geological background}

The specimens described and documented herein come from four different sites of slightly different ages: the upper Tremadocian Dol-cyn-Afon Formation of North Wales, UK; the lower Floian Tonggao Formation of Guizhou Province, China; the Tremadocian-Floian Fezouata Shale of Morocco and the Floian Landeyran Formation of the Montagne Noire, France (Fig. 1). The similarity of the fossils justifies their description together in a single paper.

The upper Tremadocian (Conophrys salopiensis Biozone) Dol-cyn-Afon Formation of North Wales, UK, contains the exceptionally preserved Afon Gam Biota: a sponge-dominated community that also includes algae, hyoliths, brachiopods, tergomyans, echinoderms, trilobites, nonbiomineralised arthropods, worms and problematic organisms (Botting and Muir, 2014; Botting et al., 2015). The tubes described herein were collected from the Amnodd Bwll stream section, near the town of Bala (Fig. 2; UK grid reference SH80753690).

The Tonggao Formation (lower Floian, Tetragraptus approximatus Biozone) of South China contains algae, echinoderms, planktic and benthic graptolites, palaeoscolecidan and soft- 
bodied worms, nonbiomineralised arthropods, rhynchonelliform and phosphatic brachiopods, gastropods and trilobites (Zhan and Jin, 2008; Van Iten et al., 2013; Muir et al., 2014; Paul et al., 2016). The studied material comes from the Tonggao Formation in the Xiayangao section, near Sandu, Guizhou Province (GPS coordinates $26^{\circ} 01.814^{\prime}$ N, 107²8.637' E). Full locality and stratigraphic details have been provided in previous papers and are not repeated here.

The Fezouata Shale of Morocco is of Tremadocian-Floian age (Lefebvre et al., 2018) and contains a diverse array of exceptionally preserved fossils (the Fezouata Biota; Van Roy et al., 2010). The specimens described herein are from several localities and stratigraphic levels.

113 The stratigraphically oldest material was collected at Oued Beni Zoli, in the lower part of the

114 Fezouata Shale (upper Tremadocian, A. murrayi Zone). This locality has yielded a diverse 115 assemblage comprising cephalopods, conulariids, echinoderms, gastropods, graptolites, 116 hyoliths, sponges and trilobites (Botting, 2007; Kröger and Lefebvre, 2012; Ebbestad and 117 Lefebvre, 2015; Lefebvre et al., 2016; Martin et al., 2016; Van Iten et al., 2016). Most other 118 specimens were collected in the upper part of the Fezouata Shale, either at Toumiat (lower 119 Floian, ?C. protobalticus Zone) or at Jbel Bou Zeroual (middle Floian, ?B. jacksoni Zone).

120 Both sites have yielded particularly abundant and diverse assemblages dominated by molluscs and trilobites, but comprising also brachiopods, conulariids, echinoderms, graptolites, hyoliths and sponges (Botting, 2016; Ebbestad, 2016; Lefebvre et al., 2016; Martin et al., 2016; Polechová, 2016; Van Iten et al., 2016). All locality and stratigraphic information has been provided in previous publications and will not be repeated here. Finally, the locality of another specimen described herein is uncertain (although probably in the Floian component of the fauna, based on the fossils present); nevertheless, we feel that the material should be published, as part of documenting the full diversity of the unit and for comparison with the other occurrences documented in this paper.

130 The Landeyran Formation of the Montagne Noire, France, is of Floian age and contains brachiopods, echinoderms, graptolites, hyolithids, machaeridians, molluscs, ostracods and trilobites (Dean, 1966; Courtessole et al., 1983; Ubaghs, 1991, 1994; Vizcaïno et al., 2001).

133 Possible agglutinated tubes are reported herein from the upper part of the Landeyran

134 Formation (H. primitivus Zone, late Floian), at les Rocs Nègres (Causses-et-Veyran, Hérault; 135 localities 15-16 in Courtessole et al., 1983, fig. 4). Additional material was noticed during 136 fieldwork in 2015 at a nearby locality called "La Falaise des Papillons" (which translates as 
137 "Butterfly Cliff", so called because of the occurrence of trilobite pygidia), in the same

138 stratigraphic interval (upper part of the Landeyran Formation, H. primitivus Zone, late Floian;

139 locality 14 in Courtessole et al., 1983, fig. 4).

140

\section{Systematic Palaeontology}

142 Some authors have treated agglutinated tubes as trace fossils (e.g. Hallam, 1960). It could be 143 argued that these structures are not the bodies of animals, but structures made by them, so it would be appropriate to use ichnotaxonomical nomenclature. However, under this definition, graptolites are also trace fossils, since the fossil remains are constructs rather than skeletons. As pointed out by Signor and McMenamin (1988), there is a continuum between trace fossils and body fossils. Those authors recognised fossils as body fossils if they were of organic construction and could be separated from the surrounding sediment; we follow this principle here and describe the specimens as body fossils.

Figured specimens are held in the National Museum of Wales, Cardiff, UK (NMW), the Nanjing Institute of Geology and Palaeontology, Nanjing, China (NIGP), the Cadi-Ayyad University, Marrakesh (AA) and the palaeontological collections of Lyon 1 University (UCBL-FSL).

Etymology. Greek, after echino (spiny, in reference here to echinoderms) and kleptes,

162 meaning thief; after the constructing organism's habit of stealing live echinoderms to

163 incorporate into its tube. Gender masculine.

Diagnosis. Straight, parallel-sided cylindrical organic tubes with moderately dense array of bioclastic particles attached, those particles being predominantly echinoderms; in some cases including semi-articulated and fully articulated individuals, some of them presumably alive at the time of incorporation. 
Remarks. Echinokleptus gen. nov. differs from Diopatrichnus Kern, 1978 in that the shell material forming the tube is not imbricated in the former and is imbricated in the latter.

Stratigraphic and geographic distribution. Known with certainty only from the upper

Tremadocian Dol-cyn-Afon Formation, at Arenig Fawr, near Bala, North Wales.

Type and only species. Echinokeptus anileis gen. et sp. nov.

Etymology. Greek anileis, meaning merciless or ruthless; referring to the efficiency with which echinoderms were collected and incorporated.

Diagnosis. As for genus.

Holotype. NMW 2012.36G.94, specimen containing glyptocystitid ossicles and including an articulated specimen of a small echinoderm of uncertain affinity (Fig. 3D).

Type locality. Stream section west of Amnodd Bwll (grid reference SH80753690), near Bala,

190 North Wales; Dol-cyn-Afon Formation (Conophyrys salopiensis Biozone, late Tremadocian).

Paratypes. Nine specimens from the stream section west of Amnodd Bwll, specimen numbers NMW 2012.36G.92 and NMW2012.36G.95 to NMW2012.36G.103.

Description. Straight, parallel-sided agglutinated tube. Length up to at least $90 \mathrm{~mm}$, diameter (flattened) 6-11 mm. Wall thickness approximately $1 \mathrm{~mm}$. The tubes are generally composed only of echinoderm material, mostly disarticulated glyptocystitid stem and brachiole ossicles (Table 1). Many specimens contain semi-articulated sections of glyptocystitid between 1 and $8 \mathrm{~mm}$ long. A few examples incorporate articulated glyptocystitids (Fig. 3B), or complete specimens of a small (c. $4 \mathrm{~mm}$ long) echinoderm of uncertain affinity (Fig. 3D, Table 1). The dominant skeletal particles are glyptocystitid remains: some tubes contain more stem ossicles

202 than brachiole remains; in others, brachiole remains are the most abundant grains (Table 1).

203 Individual glyptocystitid stem ossicles are placed such that they appear as circles, i.e. the 
articulating facet of the ossicle is outermost. Sections of stem or brachiole are attached such that the long axis is parallel to the surface of the tube, but are not arranged in any consistent orientation. The echinoderm pieces are not placed to form an overall pattern. Most of the grains do not touch others: they must have been stuck onto an underlying surface. Most of the tubes are incomplete, but where ends are preserved they show no structure.

One specimen is preserved in cross-section (Fig. 3C) with the interior filled with sediment, proving that these specimens are tubes rather than coprolites or other accumulations.

Remarks. The tube producer appears to have preferentially selected echinoderm material for use in tube building. A single specimen (Fig. 3E) includes monoplacophoran and trilobite remains within a sparsely ornamented reflective film; this specimen is not included within $E$. anileis gen. et sp. nov., and may represent a distinct, related taxon. Phosphatic brachiopods, although occurring in the same beds as the tubes, do not appear to have been used for tube construction. Even for echinoderm material, the tube producer exhibited a high degree of particle selectivity. Firstly, most of the grains used are echinoderms (either individual ossicles or articulated sections), even though other material was available in the environment. Secondly, the glyptocystitid calyx plates are present only in articulated echinoderm specimens. The only isolated glyptocystitid plates used are stem or brachiole ossicles. The calyx plates are large and distinctive, and would be visible if present. Even though there are fewer calyx than brachiole or stem plates, if the tube-maker had been selecting randomly from the grains available, some calyx plates would be seen in the tubes. Thus, the tube-maker was selecting echinoderm material, and preferred particular plates.

In contrast to deliberate incorporation of live echinoderms by the tube-maker, it is possible that the articulated glyptocystitids may represent active settling of live echinoderms on tubes containing echinoderm remains. Although articulated echinoderms were not observed attached to any other type of organism in the Dol-cyn-Afon Formation, this is partly to be expected given the palaeobiology of glyptocystitids, which were (with the probable exception of their larval stage) unattached, vagile forms. These mobile, epibenthic rhombiferans used their highly differentiated stem (with a wide, flexible proximal part, made of telescopic rings) to move over soft substrates, and to hold their theca upright above the sea floor (Guensburg and Sprinkle, 1992; Sprinkle and Guensburg, 1997). However, it is also very likely that it was used to wrap temporarily around any available erect structure, such as algae or bryozoans 
238 (see e.g. Kesling, 1967) to allow food gathering slightly higher in the water-column. If

239 polychaete tubes were erect (as suggested by comparison with living analogues), it would not

240 have been surprising that they were used as a platform by suspension-feeding organisms such

241 as glyptocystitids.

243 Support for the scenario of voluntary attachment by the glyptocystitids is provided by the fact 244 that they are type 1 echinoderms (sensu Brett et al., 1997): taxa with loosely articulated 245 skeletons, which disarticulate entirely and quickly after death (a few days to a few weeks).

246 The preservation of the entire theca with partly articulated brachioles, which were extremely

247 delicate and brittle structures, indicates that the rhombiferans associated with the tubes were

248 alive (or freshly killed), when burial occurred. If they had been trapped, glued and

249 incorporated into the tube wall, then they must have remained alive after the process, since

250 brachioles are in some cases preserved extending beyond the tube. This observation may

251 make it more likely that the echinoderms settled around the tubes rather than being incorporated into them by the tube-maker, although it is also entirely possible that the echinoderms did remain live after being fixed into the tube. Such a living disguise would help to distract attention from the tube maker in a similar manner to the use of live sponges or ascidians by modern crabs (e.g. McLay, 1982).

Contradictory evidence is also provided by some further observations. Firstly, in some cases entire glyptocystitids are preserved in a single tube, pointing in opposite directions. This is unlikely to be voluntary settlement, since the absence of attachment to any other skeletal remains suggests that they were utilising only vertical structures, in which case one would have been directed downwards. Secondly, the small, problematic eocrinoid-like echinoderm (Fig. 3D) occurs rarely within the tubes but does not possess a long, gracile column and was clearly not adapted to supporting itself by wrapping this structure around a vertical platform; it is unclear how such an echinoderm could have attached itself to these tubes at all, and this must have been deliberately incorporated.

267 Given the conflicting lines of evidence, it remains unclear whether the echinoderms were incorporated into the tube alive (and remained alive for considerable time thereafter), or, at least in the case of the larger glyptocystitids, settled deliberately onto the tubes to use them as a platform; this may be resolved by further material, but at this stage remains ambiguous. 
Agglutinated tube indet.

Figures 4A, B, 5

Material: Two specimens, NIGP154463 and NIGP156077

Occurrence: Xiayangao section, near Sandu, Guizhou Province (GPS coordinates $26^{\circ} 01.814^{\prime}$ N, $107^{\circ} 48.637^{\prime}$ E). Early Floian (Tetragraptus approximatus Biozone), 7 and 11.5 metres above the base of the Tonggao Formation.

Description: Tubes straight and parallel-sided, width 19-21 mm, length up to at least 125 $\mathrm{mm}$. Tubes composed of articulate brachiopods, gastropods and echinoderm ossicles, with echinoderm ossicles being the most common grain; for example, specimen NIGP154463 contains 41 echinoderm pieces (mostly columnals, with some calyx plates), 7 brachiopod valves, 12 gastropods, and 2 bivalve shells. Skeletal grains are closely packed and exhibit no obvious orientation. No articulated or partly articulated echinoderms are visible, and stem rather than calyx plates appear to have been used. Grains are a maximum of $9 \mathrm{~mm}$ in diameter, with the smallest recognisable grains being echinoderm columnals $0.7 \mathrm{~mm}$ in diameter; thus, there is a considerable range of grain size.

Discussion: These specimens are tubes rather than faecal pellets, because in cross-section sediment is visible between the outer layers of shelly material (Fig. 5).

Possible agglutinated tube

Material. NMW2015.34G.58; UCBL-FSL 713064, 713065; AA.JBZ.OI.167, -168, -169, 194; AA.TMT.OI.11, -26, -66, -68, -110,-201, -220, -224, -226

Occurrence. All specimens from the Tremadocian-Floian Fezouata Shale, near Zagora, Morocco. NMW2015.34G.58 from an unknown locality; UCBL-FSL specimens from Oued Beni Zoli (A. murrayi Zone, upper Tremadocian, Fezouata Formation); AA.TMT specimens from Toumiat (?C. protobalticus Zone, lower Floian, Fezouata Formation); and AA.JBZ specimens from Jbel Bou Zeroual (?B. jacksoni Zone, middle Floian, Fezouata Formation). 
307 Description. Densely packed, approximately parallel-sided linear structures, containing 308 various particles including bivalve, mollusc, hyolithid, trilobite and echinoderm remains.

309 Echinoderms include either long pluricolumnals or complete thecae of a tiny rhipidocystid-

310 like eocrinoid. Structures generally 11-30 mm wide (smallest observed width $8 \mathrm{~mm}$ ),

311 preserved length $33-105 \mathrm{~mm}$.

313 Remarks. Additional specimens of tubes have been seen in the field (JPB and BL, pers. obs.),

314 in addition to specimens in museum collections. Some of these linear structures are relatively

315 densely packed, and consist of near-monospecific assemblages of bivalves, small trilobites,

316 gastropods, or disarticulated eocrinoid columnals. Some other linear accumulations show a

317 wider diversity of shelly fragments, generally more or less of the same size, with small

318 bivalves (Redonia), small trilobites (Agerina), eocrinoid columnals (Balantiocystis),

319 hyolithids and gastropods (Carcassonnella; Fig. 6A). Such accumulations are typically linear, 320 and occur generally on surfaces with few or no other fossil(s). So far, this material has not 321 been studied by making cross-sections, and there is thus no confirmation of a hollow tube structure. At present, alternative interpretations are possible:

323 (1) Local accumulations of light, disarticulated skeletal remains by (weak) oscillatory

324 currents, within ripples or small depressions on the sea floor; this would make sense with the general palaeoenvironmental context of these levels (see Vaucher et al., 2017), and also the local occurrence of non-linear, more extensive accumulations of small shelly material, combined with the more-or-less linear arrangement of both disarticulated and almost complete specimens of glyptocystitid rhombiferans (Fig. 6B). The monospecific nature of many structures is more difficult to explain, although many bedding-plane assemblages of

330 fossils in the Fezouata Biota are of very low diversity.

331 (2) Accumulations of small shelly fragments within shallow burrows or below algal fronds

332 (i.e. tubular tempestites; see Mancosu and Nebelsick, 2017).

333 (3) Preservation of epibiotic assemblages, originally attached to algal fronds (see Havliček et 334 al., 1993).

335 (4) Bromalites produced by large predators (there were some in the Fezouata Shale, e.g. Van 336 Roy and Briggs, 2011).

338 Most of these explanations should have applied during the Cambrian and in later periods, so 339 the near-absence of similar fossils at those times, and their abundance in Lower Ordovician 
strata, make an ecological explanation reasonable. However, until further investigations of the Fezouata Biota structures are conducted, it is not possible to make a certain statement as to their nature, and at this stage we simply highlight their existence and similarity to the tubes from Wales and China.

\section{Possible agglutinated tubes}

Figures $6 \mathrm{C}, \mathrm{D}, 7$

Material. UCBL-FSL 711128 from les Rocs Nègres, Causses-et-Veyran (H. primitivus Zone, upper Floian, Landeyran Formation, Montagne Noire, France). Also field observations of abundant structures consisting of shell fragments at la Falaise des Papillons, Causses-etVeyran (H. primitivus Zone, upper Floian, Landeyran Formation, Montagne Noire, France).

Description. Elongate structures, $0.5-2 \mathrm{~cm}$ wide and up to at least $6 \mathrm{~cm}$ long, straight or slightly curved, containing brachiopod, echinoderm, mollusc and trilobite material. Particles are often large relative to diameter, and of very varied sizes within the structure. In one case observed in the field (Fig. 7A, right-hand end), there is a suggestion of sediment preserved within a three-dimensional (tubular) structure. Isolated shelly fossils were not noted on the same bedding planes as the abundant structures.

Remarks. This material may represent agglutinated tubes, as suggested by the appearance of a partial sediment infill in Fig. 7A, but may instead have other explanations, such as bromalites, tubular tempestites, sedimentary accumulations, or burrow linings. The density of the tubes, and the effectiveness of particle incorporation (removing most of the available shelly material in the sediment) are very similar to that seen in Echinokleptus anileis gen. et sp. nov., but the proportions and particle complement suggest a more distant relationship.

\section{Discussion}

\subsection{Interpretation}

Structures composed of concentrated shelly debris can represent several different types of structures: agglutinated tubes, tubular tempestites (Mancosu and Nebelsick, 2017), bromalites (e.g. Aldridge et al., 2006), remains of encrusters adhering to soft or unpreservable substrates such as algae (Havlíček et al., 1993), or armoured burrows (Buatois et al., 2017). The Welsh and Chinese specimens described herein have sediment-filled interiors (e.g. Figs 3C, 5), and 
thus must represent tubes rather than bromalites, tubular tempestites or encrusters. Moreover, the presence of complete glyptocystitids with the brachioles extending outside the tube in some of the Afon Gam examples (pers. obs, not illustrated) means that the structures cannot represent burrow linings, because placing an articulated glyptocystitid as part of a burrow lining would mean that the brachioles would be squashed together at the edge of the burrow. Thus, the producers of Echinokleptus gen. nov. and of the Chinese examples are inferred to have constructed a vertically oriented tube that projected above the sea floor (Fig. 8), in much the same manner as the modern worms Diopatra and Lanice (Myers, 1972; Jones and Jago, 1993). However, the Montagne Noire material may potentially represent armoured burrows or other structures rather than tubes, and at this stage the structures remain ambiguous.

\subsubsection{Particle selectivity}

In both the Afon Gam and the Tonggao assemblages, the tube-maker appears to have been highly selective in its choice of particles. In general, round objects were preferred, although other shapes were available in the environment. The majority of the Afon Gam tubes contain only echinoderm ossicles or entire echinoderms, although trilobites and brachiopods were present in the environment. The Tonggao specimens contain echinoderm ossicles (disarticulated only), but combined with gastropods and rhynchonelliform brachiopods.

Many extant agglutinating polychaetes show some particle selectivity, in terms of size, composition or shape of particles. Several species have been shown to preferentially select grains different in size from that most abundant in the sediment (e.g. Dorsett, 1961; Rees, 1976; Naylor and Viles, 2000; Noffke et al., 2009). Some preferentially select tabular particles or ones with at least one flat side, presumably because they are easier to stick onto the tube (e.g. Myers, 1972; Naylor and Viles, 2000; Noffke et al., 2009). The modern polychaete Owenia fusiformis prefers the biogenic component of sediments for tube-building, appearing to select particles on the basis of size and on possessing a flattened surface for ease of attachment to its organic tube (Noffke et al., 2009). In some species preferred particle size may vary over the lifetime of the organism; for example for Sabellaria, Rees (1976) reported that worms preferred larger particles later on in life.

Some ancient tube-builders were also highly selective in their choice of biogenic particles, with more impressive taxonomic recognition skills than the average second-year undergraduate (not tested quantitatively). Even some early agglutinators, such as the early 
Cambrian Volberthella, exhibited selectivity in the type of grains used (Lipps and Sylvester, 409 1968), and the latest Ediacaran to Late Ordovician Onuphionella is made entirely of mica

410 flakes (e.g. Signor and McMenamin, 1988; Muir et al., in press). Zatoń and Bond (2016)

411 described evidence for particle selectivity for a Devonian wormtube. The Carboniferous

412 agglutinated worm-tube Crininicaminus is constructed entirely from pelmatozoan ossicles

413 (Ettensohn, 1981). Zatoń et al. (2012) described agglutinated tubes from the Jurassic of

414 Poland made from ooids. The Jurassic tubes of Barnard (1956) and the Miocene examples

415 illustrated by Finger et al. (2008) are composed of foraminifera. Terebella? jinhuensis from

416 the Eocene is formed from ostracode valves (Yu and Wang, 1981). Thus, the selectivity of

417 the producer of Echinokleptus gen. nov. is consistent with other fossil and Recent examples.

418

\subsubsection{Identity of the tube-maker}

420 Echinokleptus gen. nov. is too large in diameter to have been made by foraminifera, and is 421 also much larger than the modern tubes produced by tanaidacean crustaceans (e.g. Greve, 422 1967; Langer and Long, 1994). Although morphologically similar to certain insect larval 423 constructions, these fossils greatly pre-date the appearance of insects. The high degree of 424 particle selection, and the regular, thin-walled and cylindrical morphology, rule out a 425 cnidarian affinity (compare Hallam, 1960). Based on the epifaunal projection of the tube, its 426 morphology and particle selectivity, and comparisons with extant taxa made above, a 427 polychaete annelid is the most likely producer.

\subsection{Ecological significance}

430 Agglutinated tubes may have a variety of benefits for the producing organism: tubes may 431 protect against predators (e.g. Brenchley, 1976); raise the organism above the sea floor for 432 more efficient filter feeding (e.g. Altenbach et al., 1993) or camouflage the inhabitant (e.g. 433 Myers, 1972). Some agglutinated tubes act at least partly to facilitate feeding: vertical tubes 434 projecting above the sediment surface raise the organism away from the boundary layer, 435 making filter or suspension feeding easier (e.g. Altenbach et al., 1993 for a miliolid 436 foraminiferan). The tubes themselves may also act to trap food items (see for example Lipps 437 and Ronan, 1974, in this case of a microcarnivore/deposit feeding worm). The tubes 438 described herein may have had any or all of these functions.

\subsection{Evolutionary significance}


441 Agglutinated tubes of a variety of types have been described from Cambrian and Ordovician 442 strata (e.g. Lipps and Sylvester, 1968; Signor and McMenamin, 1988; Muir et al., in press).

443 Some of these tubes exhibit remarkable particle selectivity on the part of the tube-maker, 444 such as that of the micaceous tube Onuphionella (Signor and McMenamin, 1988). Many of 445 these tubes are much smaller than the tubes described in this paper (millimetre- rather than 446 centimetre-scale), and most do not incorporate echinoderm material. One possible example 447 that is similar to Echinokleptus gen. nov. was described by Zamora and Rahman (2015) from 448 middle Cambrian strata of Spain. Their specimen consists of a linear arrangement of 38 449 juvenile cinctans (Elliptocinctus barrandei). Those authors interpreted the specimen as 450 representing a life assemblage, but an equally possible interpretation is as an agglutinated 451 tube similar to those described herein, in which case it would be the oldest record of this type 452 of tube.

454 The apparent absence of similar agglutinated tubes in most deposits could be related to the low preservation potential of the material, as the organic material binding the tube would readily decay and the component skeletal particles would become scattered in the absence of rapid burial. This type of fossil should, however, have been preserved in the numerous Burgess Shale-type deposits of the early and middle Cambrian. None appear to be found in these deposits, despite the presence of even earlier Cambrian agglutinated tubes composed exclusively of mineral grains, such as Onuphionella (Signor and McMenamin, 1988), which may also have been produced by polychaete annelids. The earliest putative tube similar to Echinokleptus is Cryptosiphon from the Ordovician of Bohemia (Prantl, 1948; Howell, 1962). Structurally, these linear accumulations of shelly material are very similar to the Moroccan and Montagne Noire material described here, but their particle selectivity is highly variable. For example, elongate clusters of agnostid trilobites have been described instead as ecological associations of trilobites with soft-bodied organisms such as octocorals (Slavíčková and Kraft, 2001), whereas similar structures were described by Havliček et al. (1993) as epibiontic communities attached to algae. Further studies are needed for assessing the full range of this material, which may include several types of structures; some of these may indeed be agglutinated tubes, but that remains to be confirmed.

The near-contemporaneous presence of similar tubes in at least Avalonia and South China is, at first glance, remarkable. These sites were located on different continental blocks and at different latitudes during the Ordovician, with South China being situated on the equator or at 
low latitude, Morocco and the Montagne Noire at high latitude, and North Wales (Avalonia) at intermediate latitude but relatively close to the Moroccan/Armorican region (Fig. 1; Torsvik and Cocks, 2009; Cocks and Torsvik, 2013). Despite the separation of South China from the other regions, there was some faunal continuity (Martin et al., 2016; Lefebvre et al., 2016), probably facilitated by the long Gondwanan margin that nearly connected the continental blocks. It remains to be tested whether the group had a truly cosmopolitan distribution pattern.

The widespread appearance of this type of large agglutinated tube in the Early Ordovician indicates that some diversification of annelids was occurring during the early part of the GOBE, consistent with the evidence from scolecodonts (Hints and Eriksson, 2007). However, the unusually large size, and (perhaps in some cases) aggressive collecting behaviour of live animals suggest that unusual ecological conditions were also operational at this time, with at least some significant ecological changes from the middle Cambrian. The large size (especially relative to early Cambrian tubes agglutinated from mineral particles) suggests that a significant food supply was available, either though filter-feeding or possibly by efficient prey capture.

Interpretation of life habits in this case is necessarily highly speculative, but the above scenario is consistent with living polychaete behaviour, and with the observations of the fossils. If the worms were suspension feeders, then it is also consistent with the early stages of the GOBE being partly in response to a major diversification of phytoplankton (Servais et al., 2016). Along with the spectacular increase in sponge ecological dominance seen in the Afon Gam Biota, and relative decline of arthropods (Botting et al., 2015), these tube-makers may also have been finding novel ways of exploiting a much richer suspended food supply. Furthermore, it remains unclear whether the makers of the tubes in different regions were closely related, and therefore whether they had similar feeding strategies; parallel evolution of similar tube construction among suspension feeders and predators is also possible.

\section{Conclusions}

505 Large agglutinated tubes (Echinokleptus anileis gen. et sp. nov.) made of skeletal particles

506 (predominantly articulated and disarticulated echinoderms) are described from the Lower

507 Ordovician Dol-cyn-Afon Formation of Wales. Similar tubes (although incorporating

508 different types of material) are present in Lower Ordovician strata of South China, and 
possibly also Morocco and France. By analogy with modern forms, the tubes were probably produced by an infaunal polychaete, but projected above the sediment surface. The occurrence of similar agglutinated tubes on different continental blocks and at different

512 palaeolatitudes indicates that this type of structure was widespread generally during the Early

513 Ordovician, and implies some diversification of annelids, at least in their ecology, as part of 514 the GOBE.

Acknowledgements

517 The assistance in the field of Naomi Jordan, Tess Ormrod, Neil Owen and Jennifer Rodley 518 (Wales); Jih-Pai Lin, Li Xiangfeng, Ng Tin-Wai and Yang Zaichun (China); Peter Van Roy 519 (Morocco); and Eric Monceret (France) is gratefully acknowledged. Access to the Welsh 520 sites was facilitated by Bob Matthews, Countryside Commission for Wales. LAM received 521 funding from China Postdoctoral Science Foundation, no. 20110490136 and from a CAS 522 President's International Fellowship Initiative (no. 2018VCB0014). Welsh fieldwork was funded by the National Natural Sciences Foundation of China Young International Fellowships, no. 41150110152 and National Geographic Society's Committee for Research and Exploration (\#9063-12) to JPB. JPB was additionally supported by Chinese Academy of Sciences Fellowships for Young International Scientists grant no. 2010Y2ZA03. Neil Owen generously provided the excellent reconstruction in Figure 7. We are grateful to Luis Buatois, Gabriela Mángano, James Nebelsick and Ursula Toom for helpful discussions, and Olev Vinn for his supportive review. This paper is a contribution to the International Geoscience Programme (IGCP) Project 653 - The onset of the Great Ordovician Biodiversification Event.

\section{References}

Aldridge, R.J., Gabbott, S.E., Siveter, L.J., Theron, J.N., 2006. Bromalites from the Soom Shale Lagerstätte (Upper Ordovician) of South Africa: palaeoecological and palaeobiological implications. Palaeontology 49, 857-871.

Altenbach, A.V., Heeger, T., Linke, P., Spindler, M., Thies, A., 1993. Milionella subrotunda (Montagu), a miliolid foraminifer building large detritic tubes for a temporary epibenthic lifestyle. Marine Micropaleontology 20, 293-301. Kinberg, 1865 (Onuphidae) in Hawaii: community structure, and sediment stabilizing properties. Zoological Journal of the Linnean Society 80, 191-199. 
Barnard, T., 1956. An unusual worm tube from the Lower Lias. Journal of Paleontology 30, 1273-1274.

Bell, S., 1985. Habitat complexity of polychaete tube-caps: influence of architecture on dynamics of a meioepibenthic assemblage. Journal of Marine Research 43, 647-671.

Botting, J.P., 2007. 'Cambrian' demosponges in the Ordovician of Morocco: insights into the early evolutionary history of sponges. Geobios 40, 737-748.

Botting, J.P., 2016. Diversity and ecology of sponges in the Early Ordovician Fezouata Biota, Morocco. Palaeogeography, Palaeoclimatology, Palaeoecology 460, 75-86.

Botting, J.P., Muir, L.A., 2014. First post-Cambrian records of the reticulosan sponges Valospongia and Hintzespongia from the late Tremadocian of North Wales. Acta Palaeontologica Polonica 59, 241-252.

Botting, J.P., Muir, L.A., Jordan, N., Upton, C., 2015. An Ordovician variation on Burgess Shale-type biotas. Scientific Reports 5, 9947, doi:10.1038/srep09947.

Brenchley, G.A., 1976. Predator detection and avoidance: ornamentation of tube-caps of Diopatra spp. (Polychaeta: Onuphidae). Marine Biology 38, 179-188.

Brett, C.E., Moffat, H.A., Taylor, W.L., 1997. Echinoderm taphonomy, taphofacies, and Lagerstätten. Paleontological Society Papers 3, 147-190.

Buatois, L.A., Wisshak, M., Wilson, M.A., Mángano, M.G., 2017. Categories of architectural designs in trace fossils: a measure of ichnodisparity. Earth-Science Reviews 164, $102-181$.

Burke, C.D., Mazzullo, S.J., Bischoff, W.D., Dunn, R.K., 1992. Environmental setting of Holocene sabellariid worm reefs, northern Belize. Palaios 7, 118-124.

Cocks, L.R.M., Torsvik, T.H., 2013. The dynamic evolution of the Palaeozoic geography of eastern Asia. Earth-Science Reviews 117, 40-79.

Courtessole, R., Marek, L., Pillet, J., Ubaghs, G., Vizcaïno, D., 1983. Calymenina, Echinodermata et Hyolitha de l'Ordovicien inférieur de la Montagne Noire. Mémoire de la Société d'Etudes Scientifiques de l'Aude, Carcassonne, 1-62.

Dean, W., 1966. The Lower Ordovician stratigraphy and trilobites of the Landeyran valley and the neighbouring district of the Montagne Noire. Bulletin of the British Museum (Natural History), Geology 12, 245-353.

de Gilbert, J.M., 1996. Diopatrichnus odlingi n. isp. (annelid tube) and associated ichnofabrics in the White Limestone (M. Jurassic) of Oxfordshire: sedimentological and palaeoecological significance. Proceedings of the Geologists' Association 107, 189-198. 
Dorsett, D.A., 1961. The behaviour of Polydora ciliata (Johnst.). Tube-building and burrowing. Journal of the Marine Biological Association of the United Kingdom 41, $577-590$.

Ebbestad, J.O., 2016. Gastropoda, Tergomya and Paragastropoda (Mollusca) from the Lower Ordovician Fezouata Formation, Morocco. Palaeogeography, Palaeoclimatology, Palaeoecology 460, 87-96.

Ebbestad, J.O., Lefebvre, B., 2015. An unusual onychochilid mollusc from the Ordovician (Tremadocian) Fezouata Formation, Morocco. Geobios 48, 427-438.

Ekdale, A.A., Lewis, D.W., 1993. Sabellariid reefs in Ruby Bay, New Zealand: a modern analogue of Skolithos "piperock" that is not produced by burrowing activity. Palaios $8,614-620$.

Eckman, J.E., Nowell, A.R.M., Jumars, P.A., 1981. Sediment destabilization by animal tubes. Journal of Marine Research, 39, 361-374.

Ettensohn, F.R., 1981. Crininicaminus haneyensis, a new agglutinated worm tube from the Chesterian of east-central Kentucky. Journal of Paleontology 55, 479-482.

Finger, K.L., Flenniken, M.M., Lipps, J.H., 2008. Foraminifera used in the construction of Miocene polychaete worm tubes, Monterey Formation, California, USA. Journal of Foraminiferal Research 38, 277-291.

Fischer, R., Galli Oliver, C., Reitner, J., 1989. Skeletal structure, growth, and paleoecology of the patch reef-building polychaete worm Diplochaetetes mexicanus Wilson, 1986 from the Oligocene of Baja California (Mexico). Geobios 22, 761-775.

Frey, R.W., 1970. The Lebensspuren of some common marine invertebrates near Beaufort, North Carolina. II. Anemone burrows. Journal of Paleontology 44, 308-311.

Gherardi, F., Cassidy, P.M., 1995. Life history patterns of Discorsopagurus schmitti, a hermit crab inhabiting polychaete tubes. Biological Bulletin 188, 68-77.

Gooday, A., 1984. Records of deep-sea rhizopod tests inhabited by metazoans in the Northeast Atlantic. Sarsia 69, 45-53.

Gooday, A.J., Levin, L.A., Thomas, C.L., Hecker, B., 1992. The distribution and ecology of Bathysiphon filiformis Sars and B. major de Folin (Protista, Foraminiferida) on the continental slope off North Carolina. Journal of Foraminiferal Research 22, 129-146.

Greve, L., 1967. On the tube building of some Tanaidacea. Sarsia 29, 295-298.

Grube, A., 1850. Die Familien der Anneliden. Archiv für Naturgeschichte 16, 249-364.

Guensburg, T.E., Sprinkle, J., 1992. Rise of echinoderms in the Paleozoic Evolutionary Fauna: significance of paleoenvironmental controls. Geology 20, 407-410. 
Hallam, A., 1960. Kulindrichnus langi, a new trace-fossil from the Lias. Palaeontology 3, 6468.

613 Hannah, M.J., Collen, J.D., 1995. An occurrence of the tube fossil Torlessia mackayi Bather, 6141906 from southwest Wellington, New Zealand. New Zealand Journal of Geology and Geophysics 38, 117-119.

616 Harper, D.A.T., 2006. The Ordovician biodiversification: setting an agenda for marine life: 617 Palaeogeography, Palaeoclimatology, Palaeoecology 232, 148-166.

618 Hassack, D., Holdich, M., 1987. The tubiculous habit amongst the Tanaidacea (Crustacea, 619 Peracarida) with particular reference to deep-sea species. Zoologica Scripta 16, 223233.

Havlíček V., Vaněk, J., Fatka, O., 1993. Floating algae of the genus Krejciella as probable hosts of epiplanktonic organisms (Dobrotivá Series, Ordovician; Prague basin). Journal of the Czech Geological Society 38, 79-87.

Howell, B.F., 1962. Worms. In: Moore, R.C., (Ed.), Treatise on Invertebrate Paleontology,

Kern, J.P., 1978. Paleoenvironment of new trace fossils from the Eocene Mission Valley Formation, California. Journal of Paleontology 52, 186-194.

Kesling, R.V., 1967. Cystoids. In: Moore, R.C., (Ed.), Treatise on Invertebrate Paleontology, Press, S85-S267.

Kirtley, D.W., Tanner, W.F., 1968. Sabelariid worms; builders of a major reef type. Journal of Sedimentary Research 38, 73-78.

Kröger, B., Lefebvre, B., 2012. Palaeogeography and palaeoecology of early Floian (Early

643 Lamarck, J.B.P.A., 1809. Philosophie zoologique. $442+450$ pp. Dentu, Paris. 
Langer, M., Long, D.J., 1994. Association of benthic foraminifera with a gammarid amphipod on tidal flats of San Francisco Bay, California. Journal of Coastal Research $10,877-883$.

Lefebvre, B., Allaire, N., Guensburg, T.E., Hunter, A.W., Kouraïss, K., Martin, E.L.O., Nardin, E., Noailles, F., Pittet, B., Sumrall, C.D., Zamora, S., 2016. Palaeoecological aspects of the diversification of echinoderms in the Lower Ordovician of central AntiAtlas, Morocco. Palaeogeography, Palaeoclimatology, Palaeoecology 460, 97-121.

Lefebvre, G., Gutierrez-Marco, J.C., Lehnert, O., Martin, E.L.O., Nowak, H., Akodad, M., El Hariri, K., Servais, T., 2018. Age calibration of the Lower Ordovician Fezouata Lagerstätte, Morocco. Lethaia 51, 296-311.

Lipps, J.H., Ronan, T.E. Jr., 1974. Predation on foraminifera by the polychaete worm, Diopatra. Journal of Foraminiferal Research 4, 139-143.

Lipps, J.H., Sylvester, A.G., 1968. The enigmatic Cambrian fossil Volborthella and its occurrence in California. Journal of Paleontology 42, 329-336.

Mancosu, A., Nebelsick, J.H., 2017. Palaeoecology and taphonomy of spatangoid-dominated echinoderm assemblages: a case study from the Early-Middle Miocene of Sardinia, Italy. Palaeogeography, Palaeoclimatology, Palaeoecology 466, 334-352.

Mángano, M.G., Droser, M.L., 2004. The ichnologic record of the Ordovician Radiation. In: Webby, B.D., Paris, F., Droser, M.L., Percival, I.G., (Eds.), The Great Ordovician Biodiversification Event. Columbia University Press, New York, 369-379.

Martin, E.L.O., Vidal, M., Vizcaïno, D., Vaucher, R., Sansjofre, P., Lefebvre, B., Destombes, J., 2016. Biostratigraphic and palaeoenvironmental controls on the trilobite associations from the Lower Ordovician Fezouata Shale of the central Anti-Atlas, Morocco. Palaeogeography, Palaeoclimatology, Palaeoecology 460, 142-154.

McLay, C.L., 1982. Population biology of the sponge crab Cryptodromia hilgendorfi (Dromiacea) in Moreton Bay, Queensland, Australia. Marine Biology 70, 317-326.

Miller, W. III, 2005. Giant Bathysiphon (Astrorhizina: Foraminifera) from the Late Cretaceous Hunters Cove Formation, Southwestern Oregon. Journal of Paleontology 79, 389-394.

Muir, L.A., Ng, T.-W., Li, X.-F., Zhang, Y.-D., Lin, J.-P., 2014. Palaeoscolecidan worms and a possible nematode from the Early Ordovician of South China. Palaeoworld 23, 1524.

Muir, L.A., Botting, J.P., Walker, S.N.A., Schiffbauer, J.D., MacGabhann, B.A., in press. Onuphionella corusca sp. nov.: an early Cambrian-type agglutinated tube from Upper 
Ordovician strata of Morocco. In: Hunter, A.W., Alvaro, J.J., Lefebvre, B., Van Roy, P., Zamora, S., (Eds.), The Great Ordovician Biodiversification Event: insights from the Tafilalt Biota, Morocco. Geological Society Special Publications, 485. doi:10.1144/SP485.7

Muscente, A.D., Schiffbauer, J.D., Broce, J., Laflamme, M., O’Donnell, K., Boag, T.H., Meyer, M., Hawkins, A.D., Huntley, J.W., McNamara, M., MacKenzie, L.A., Stanley, G.D. Jr, Hinman, N.W., Hofmann, M.H., Xiao, S., 2017. Exceptionally preserved fossil assemblages through geologic time and space. Gondwana Research 48, 164-188.

Myers, A.C., 1972. Tube-worm-sediment relationships of Diopatra cuprea (Polychaeta: Onuphidae). Marine Biology 17, 350-356.

Naylor, L.A., Viles, H.A., 2000. A temperate reef builder: an evaluation of the growth, morphology and composition of Sabellaria alveolata (L.) colonies on carbonate platforms in South Wales. Geological Society, London, Special Publication 178, 919.

Noffke, A., Hertweck, G., Kröncke, I., Wehrmann, A., 2009. Particle size selection and the tube structure of the polychaete Owenia fusiformis. Estuarine, Coastal and Shelf Science 81, 160-168.

Paul, C.R.C., Donovan, S.K., Muir, L.A., Botting, J.P., Lin, J.-P., Zhang, Y., 2016. Primitive Ordovician (Floian) echinoderms from Sandu, Guizhou Province, China, and their significance. Geological Journal 51, 143-156.

Polechová, M., 2016. The bivalve fauna from the Fezouata Formation (Lower Ordovician) of Morocco and its significance for palaeobiogeography, palaeoecology and early diversification of bivalves. Palaeogeography, Palaeoclimatology, Palaeoecology 460, $155-169$.

Prantl, F., 1948. Some terebelloid remains from the Ordovician of Bohemia. České Spolčnosti Nauk, Trída Mathematico-Přrirodorvědecka, Věstnik 8, 1-8.

Rees, C.P., 1976. Sand grain size distribution in tubes of Sabellaria vulgaris Verrill. Chesapeake Science 17, 59-61.

Servais, T., Owen, A.W., Harper, D.A.T., Kröger, B., Munnecke, A., 2010. The Great Ordovician Biodiversification Event (GOBE): the palaeoecological dimension: Palaeogeography, Palaeoclimatology, Palaeoecology 294, 99-119.

Servais, T., Perrier, V., Danielian, T., Klug, C., Martin, R., Munnecke, A., Nowak, H., Nützel, A., Vandenbroucke, T.R.A., Williams, M., Rasmussen., C.M.Ø., 2016. The 
onset of the 'Ordovician Plankton Revolution' in the late Cambrian. Palaeogeography, Palaeoclimatology, Palaeoecology 458, 12-28.

Signor, P.W., McMenamin, 1988. The Early Cambrian worm tube Onuphionella from California and Nevada. Journal of Paleontology 62, 233-240.

Slavíčková, J., Kraft, P., 2001. Remarks on the palaeoecology of agnostid trilobites. Journal of the Czech Geological Society 46, 215-218.

Sprinkle, J., Guensburg, T.E., 1997. Early radiation of echinoderms. Paleontological Society Papers 3, 205-224.

Thomas, A.T., Smith, M.P., 1998. Terebellid polychaete burrows from the Lower Palaeozoic. Palaeontology 41, 317-333.

Torsvik, T.H. 2009. BugPlates: Linking biogeography and palaeogeography. Available online at http://www.iggl.no/resources.html (accessed September 2017).

Torsvik, T.H., Cocks, L.R.M., 2009. The Lower Palaeozoic palaeogeographical evolution of the northeastern and eastern peri-Gondwanan margin from Turkey to New Zealand. Geological Society, London, Special Publications 325, 3-21.

Ubaghs, G., 1991. Deux Stylophora (Homalozoa, Echinodermata) nouveaux pour l'Ordovicien inférieur de la Montagne Noire (France méridionale). Paläontologische Zeitschrift 65, 157-171.

Ubaghs, G., 1994. Echinodermes nouveaux (Stylophora, Eocrinoidea) de l'Ordovicien inférieur de la Montagne Noire (France). Annales de Paléontologie 80, 107-141.

Van Iten, H., Muir, L.A., Botting, J.P., Zhang, Y.-D., Lin, J.-P., 2013. Conulariids and Sphenothallus (Cnidaria, Medusozoa) from the Tonggao Formation (Lower Ordovician, China). Bulletin of Geosciences 88, 713-722.

Van Iten, H., Muir, L., Simões, M.G., Leme, J.M., Marques, A.C., Yoder, N., 2016. Palaeobiogeography, palaeoecology and evolution of Lower Ordovician conulariids and Sphenothallus (Medusozoa, Cnidaria), with emphasis on the Fezouata Shale of southeastern Morocco. Palaeogeography, Palaeoclimatology, Palaeoecology 240, $170-178$.

Van Roy, P., Briggs, D.E.G., 2011. A giant Ordovician anomalocaridid. Nature 473, 510513.

Van Roy, P., Orr, P.J., Botting, J.P., Muir, L.A., Vinther, J., Lefebvre, B., el Hariri, K., Briggs, D.E.G., 2010. Ordovician faunas of Burgess Shale type. Nature 465, 215-218. 
Vaucher, R., Pittet, B., Martin, E.L.O., Lefebvre, B., Hormière, H., 2017. A wave-dominated tide-modulated model for the Lower Ordovician of the Anti-Atlas. Sedimentology 64, $777-807$.

Vinn, O., Luque, J., 2013. First record of a pectinariid-like (Polychaeta, Annelida) agglutinated worm tube from the Late Cretaceous of Columbia. Cretaceous Research $41,107-110$.

Vizcaïno, D., Álvaro, J.J., Lefebvre, B., 2001. The Lower Ordovician of the southern Montagne Noire. Annales de la Société Géologique du Nord 8, 213-220.

Yu, C.-M., Wang, H.-J., 1981. Some tube-like fossils from the Early Tertiary of northern Jiangsu. Acta Palaeontologica Sinica 20, 406-417.

Zatoń, J., Bond, D.P.G., 2016. Insight into tube-building behaviour and palaeoecology of some agglutinating worms from the Upper Devonian of Nevada, USA. Palaeogeography, Palaeoclimatology, Palaeoecology 445, 138-146.

Zamora, S., Rahman, I.A., 2015. Palaeobiological implications of a mass-mortality assemblage of cinctans (Echinodermata) from the Cambrian of Spain. In: Zamora, S., Rábano, I., (Eds), Progress in Echinoderm Palaeobiology. Cuadernos del Museo Geominero 19, 203-206.

Zatoń, J., Kano, Y., Wilson, M.A., Filipiak, P., 2012. Unusual tubular fossils associated with microbial crusts from the Middle Jurassic of Poland: agglutinated polychaete worm tubes? Palaios 27, 550-559.

Zhan, R., Jin J., 2008. Onshore migration of a deep-water brachiopod fauna from the Lower Ordovician Tonggao Formation, Jiangnan Slope, southeastern Guizhou Province, South China. Canadian Journal of Earth Sciences 45, 141-157. 
Figure 1: Temporal and spatial distribution of agglutinated tubes. A. Palaeogeographic map showing the positions of the study sites during the Ordovician. $1=$ Wales, $2=$ Morocco, $3=$ France, 4 = South China. Map plotted using BugPlates (Torsvik, 2009) for the early Floian (478 Ma). B. Stratigraphic column showing the ages of the tube-bearing sites.

Figure 2: Locality map for the Afon Gam agglutinated tubes. The inset map shows the position of the study site within the UK.

Figure 3: Agglutinated tubes from Wales. All specimens from Amnodd Bwll, near Bala, North Wales. A-D, Echinokleptus anileis gen. et sp. nov. A, NMW 2012.36G.92, Specimen containing isolated echinoderm ossicles. B, NMW 2012.36G.96, specimen containing an articulated portion of a glyptocystitid. C, NMW 2012.36G.95, natural cross-section through an agglutinated tube. D, NMW 2012.36G.94, holotype, specimen composed largely of disarticulated glyptocystitid plates and containing a small echinoderm of uncertain affinity (arrowed). E, NMW 2012.36G.93, agglutinated tube containing monoplacophoran and trilobite remains. Scale bars: A $10 \mathrm{~mm}$; B, C, E. $5 \mathrm{~mm}$; D $3 \mathrm{~mm}$.

Figure 4: Agglutinated tubes from China and Morocco. A, B. Agglutinated tube indet. from the Tonggao Formation at Xiayangao, Guizhou Province. A, NIGP154463. B, NIGP156077. C, Possible agglutinated tube from the Fezouata Shale, Morocco. NMW2015.34G.58. Scale bar $10 \mathrm{~mm}$ in each case.

Figure 5: Side view showing cross-section of agglutinated tube indet. (NIGP154463) from the Tonggao Formation at Xiayangao, Guizhou Province. Note the sediment (arrowed) in the middle of the tube. Scale bar $10 \mathrm{~mm}$.

Fig. 6: Possible tubes from Lower Ordovician strata of Morocco and France. A, AA.JBZ.OI.167, from Jbel Bou Zeroual (middle Floian Fezouata Formation, near Zagora, Morocco), linear accumulation of bivalves and gastropods, with detail inset. B, UCBL-FSL 713064, from Oued Beni Zoli (upper Tremadocian Fezouata Formation, near Zagora,

800 Morocco), elongate structure composed largely of glyptocystitid echinoderms, including semi-articulated columns and isolated thecal plates. C-D, UCBL-FSL 711128 (upper Floian 
802 Landeyran Formation, Les Rocs Nègres, Causses-et-Veyran (Montagne Noire, France) C,

803 elongated accumulation of primarily bivalve shells with some echinoderm debris. D, detail

804 showing mostly intact bivalve shells with a few fragments. Scale bars $10 \mathrm{~mm}$.

805

806 Figure 7: Field photographs of possible agglutinated tubes at Falaise des Papillons, Causses-

807 et-Veyran (Montagne Noire, France). Photographs taken 17 April 2015. The tape measure is 808 marked in centimetres.

809

810 Figure 8: Reconstruction of Echinokleptus anileis gen. et sp. nov. in life with inhabitant

811 (reconstructed as a polychaete worm). Agglutinated particles consist of glyptocystitids and

812 pieces of echinoderm. Also illustrated are hyolithids and a free-living glyptocystitid. Image

813 drawn by and copyright Neil Owen.

814 

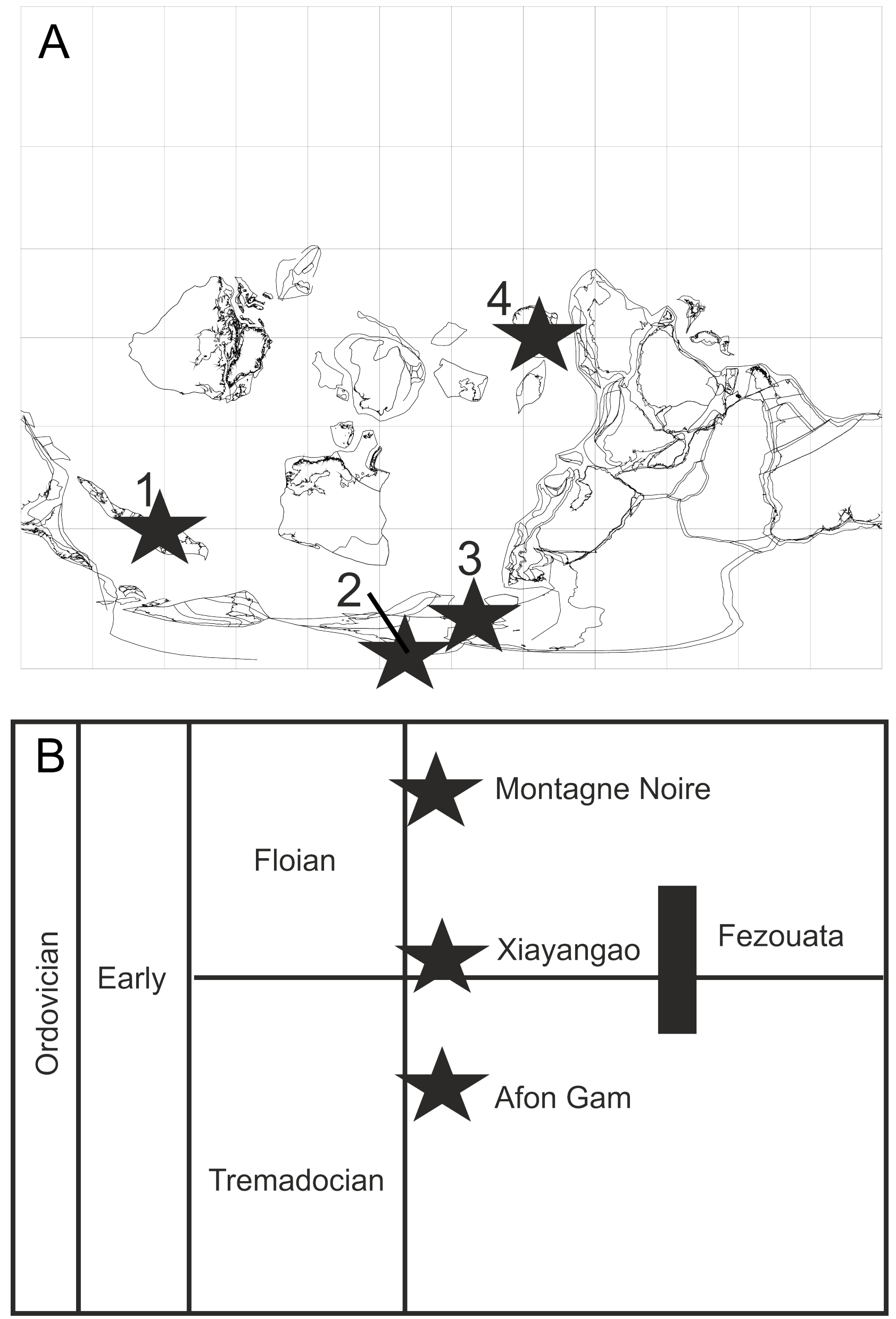



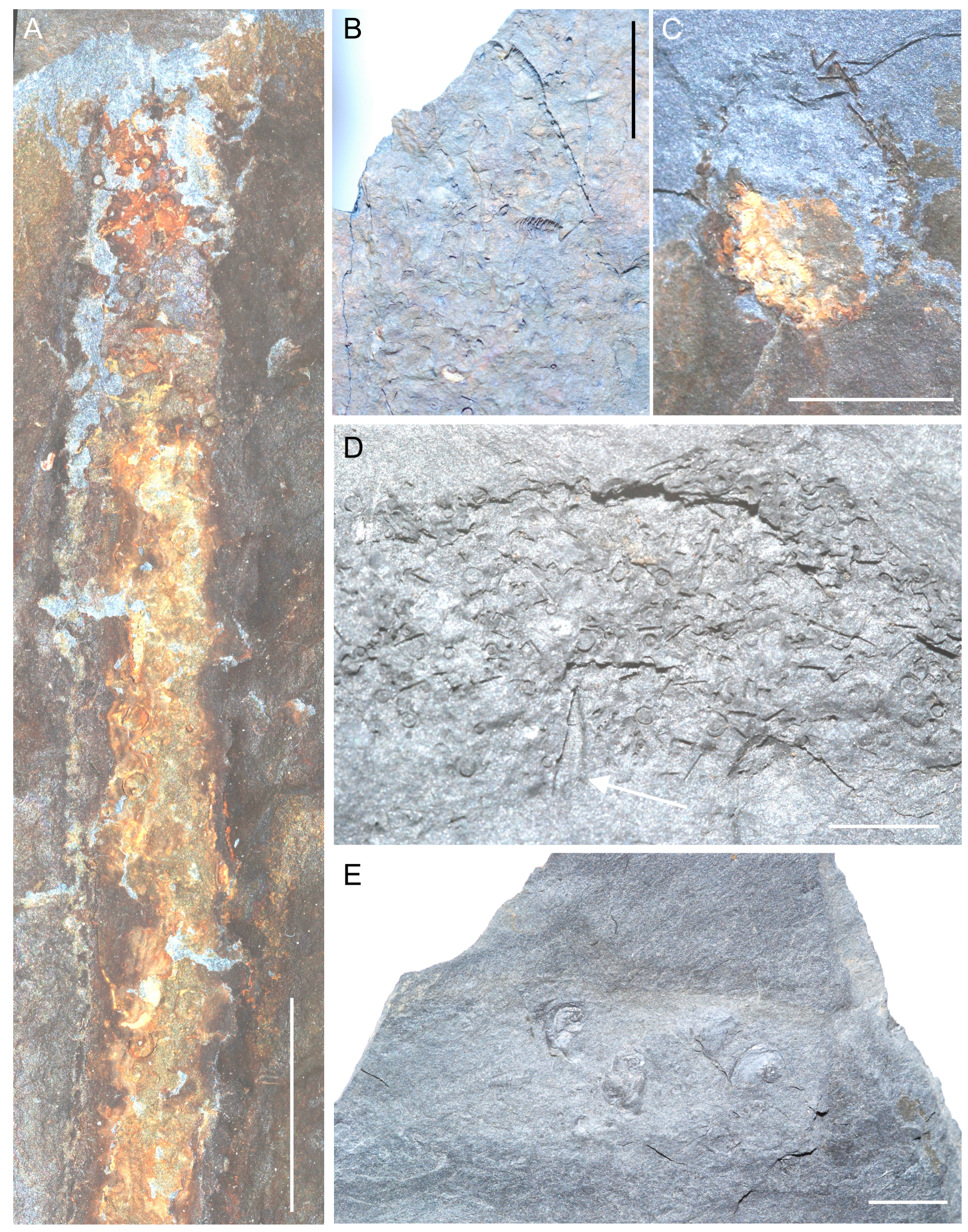




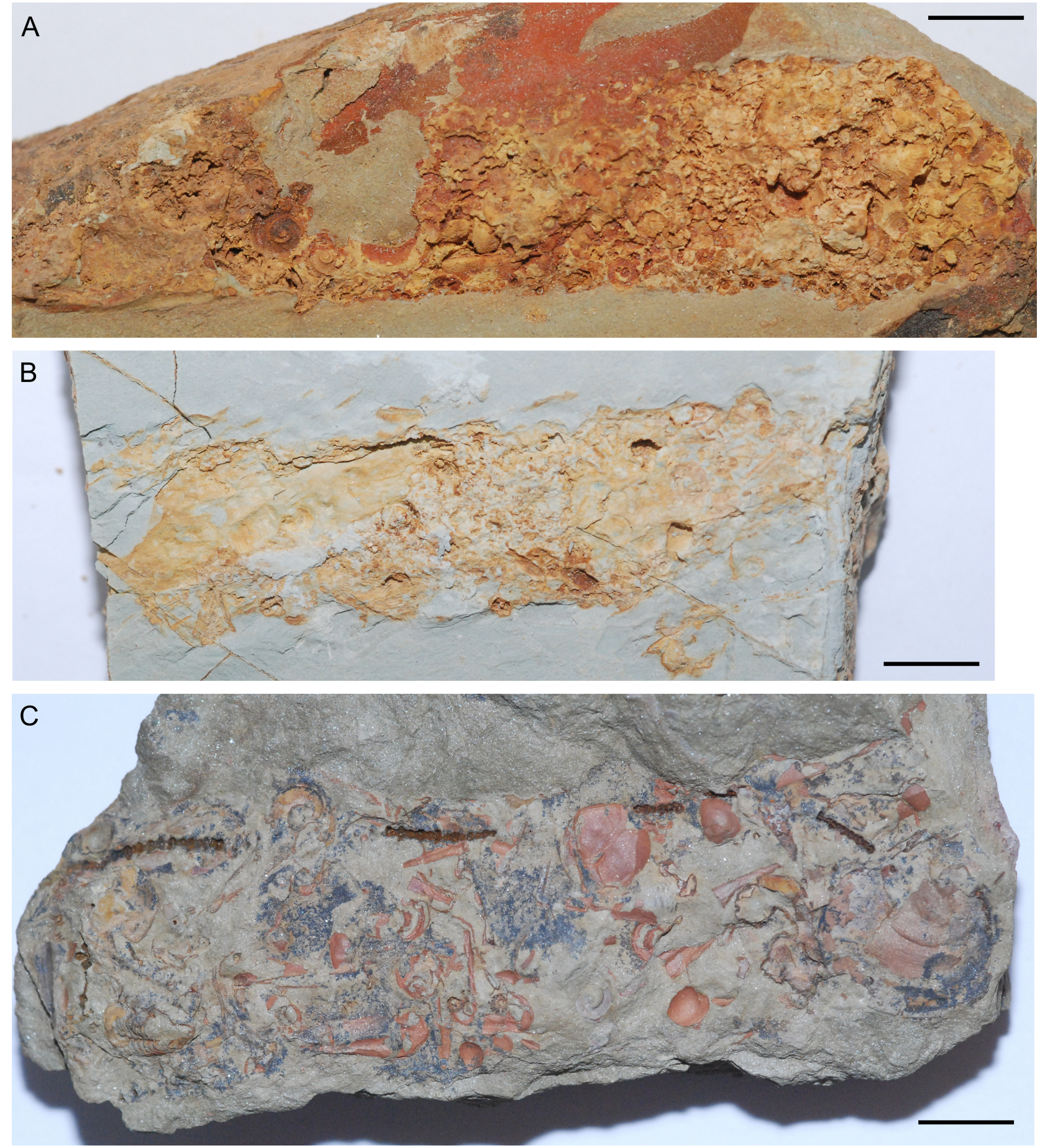



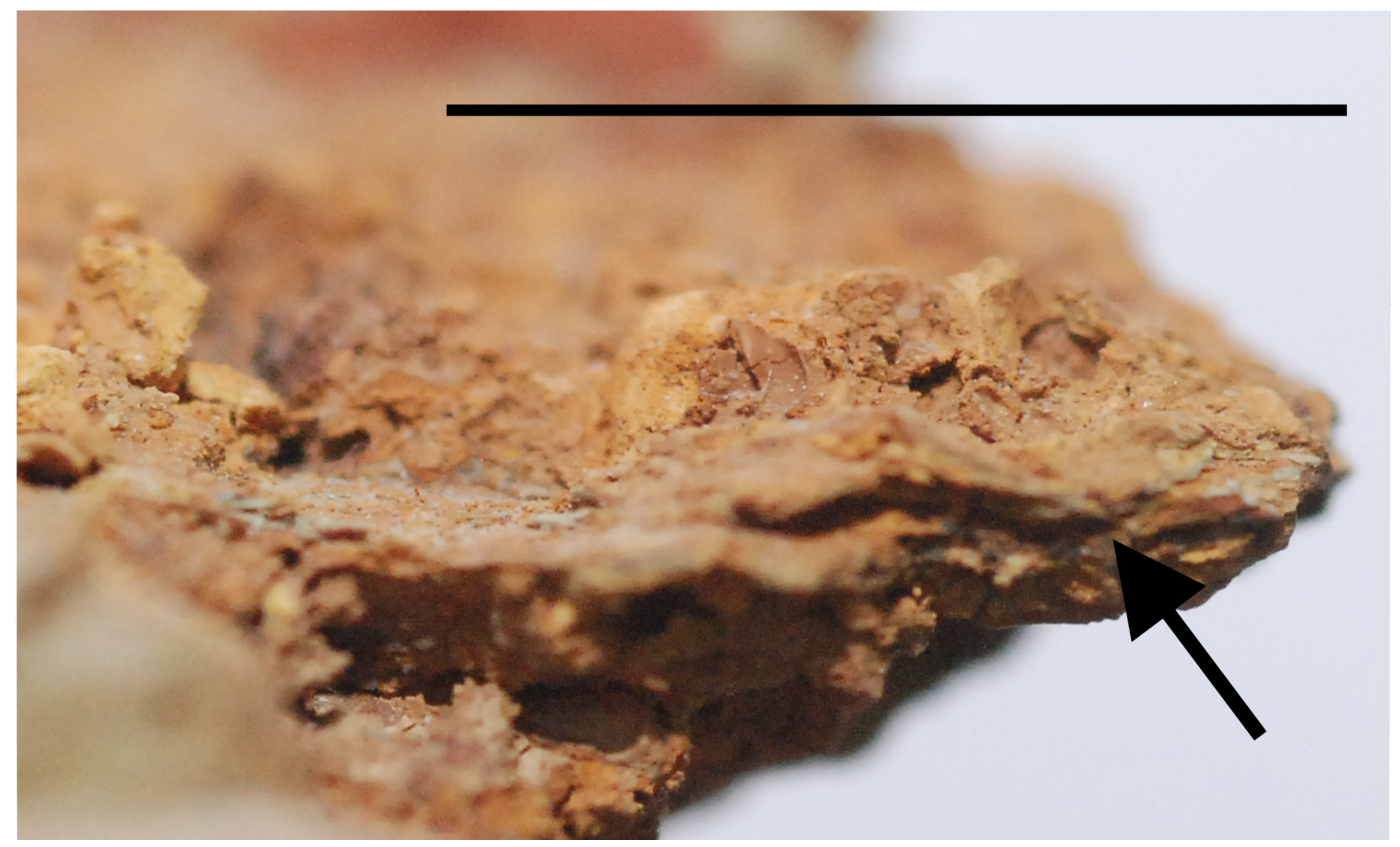





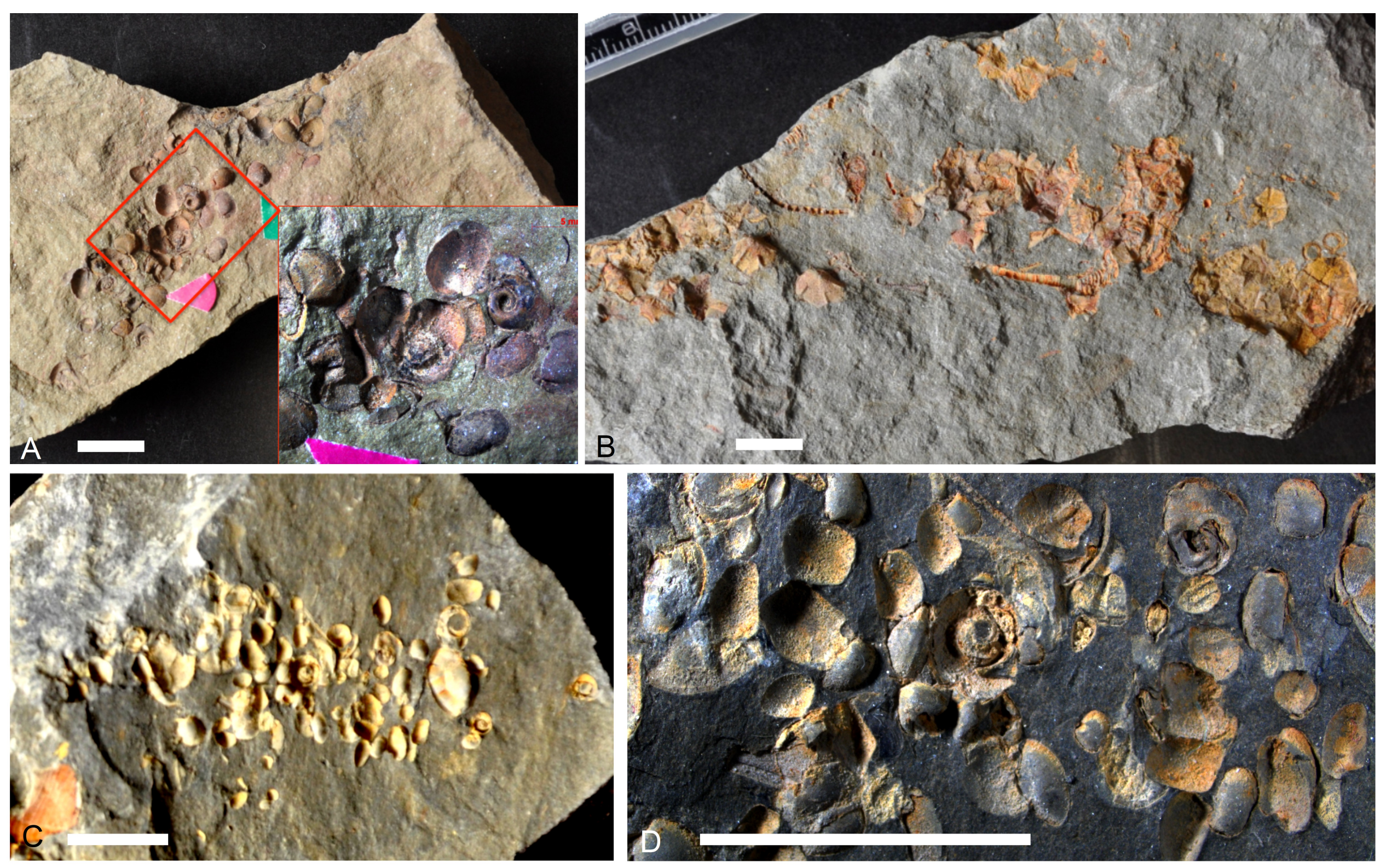





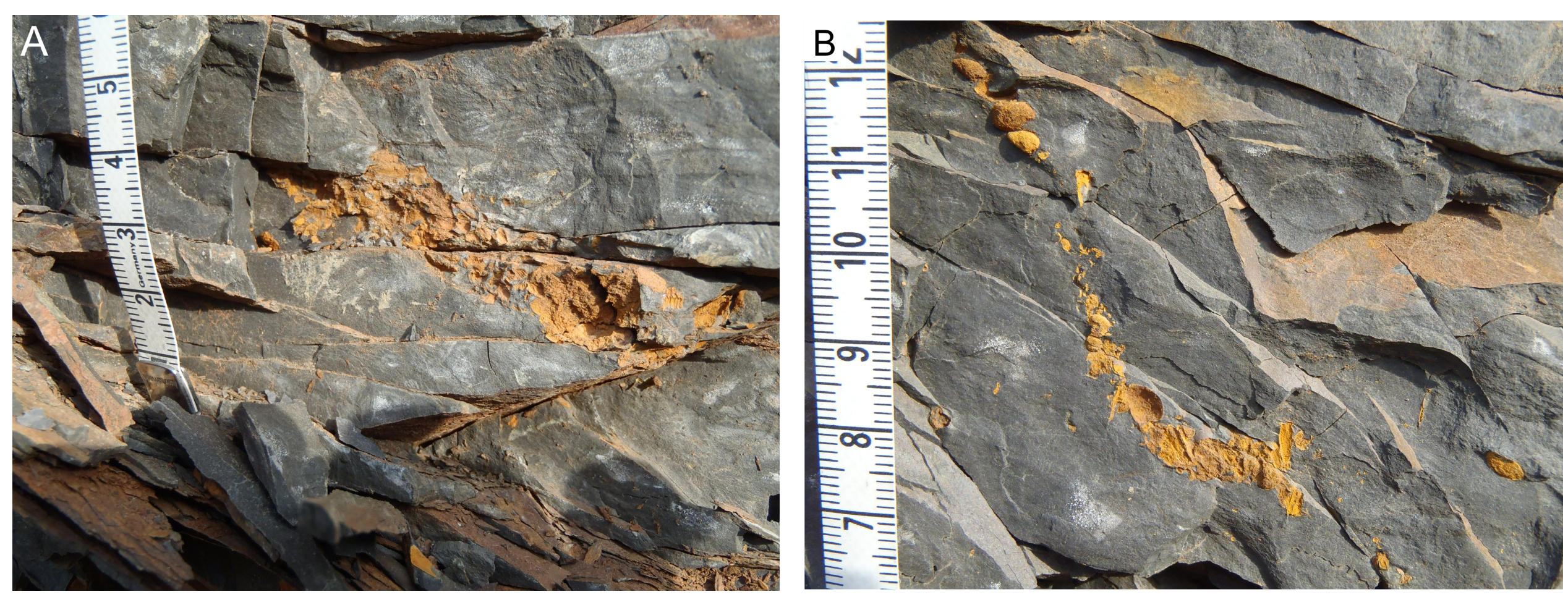


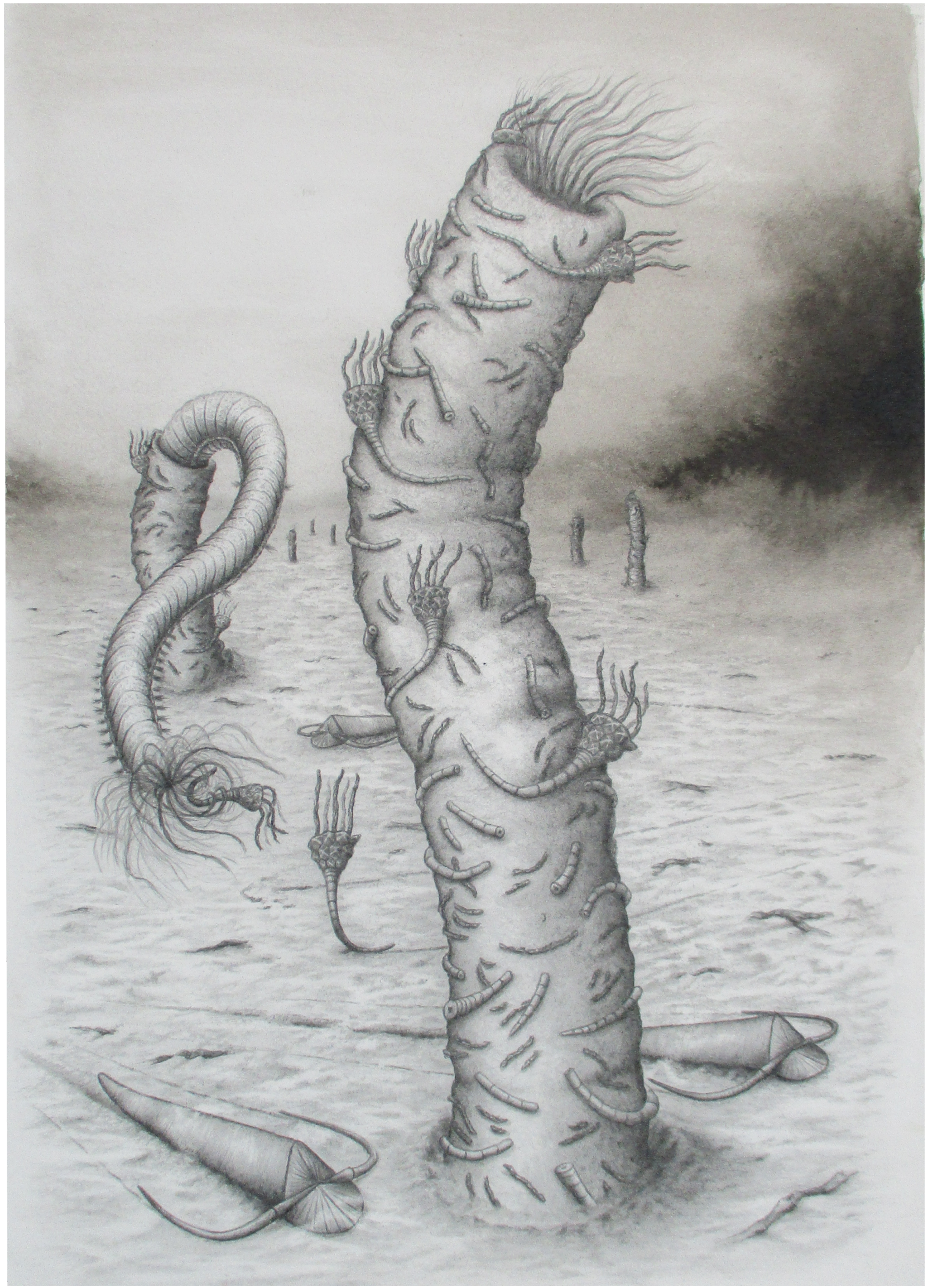


Table 1: Types, abundance and maximum sizes (diameter for stem ossicles, length for other types) of skeletal grains in Echinokleptus anileis gen. et sp. nov. Data are given in the form number of elements (maximum size). Sizes are in millimetres. It was not possible to obtain reliable measurements from specimens NMW2012.36G.92, 95 and 100.

\begin{tabular}{|c|c|c|c|c|}
\hline Specimen number & $\begin{array}{l}\text { Partly or fully } \\
\text { articulated } \\
\text { glyptocystitid }\end{array}$ & $\begin{array}{l}\text { Glyptocystitid } \\
\text { brachioles }\end{array}$ & $\begin{array}{l}\text { Glyptocystitid } \\
\text { stem ossicles }\end{array}$ & $\begin{array}{l}\text { Other skeletal } \\
\text { components }\end{array}$ \\
\hline NMW 2012.36G.94 & & $>10(2.5 \mathrm{~mm})$ & $>40(0.5 \mathrm{~mm})$ & $\begin{array}{l}\text { Small echinoderm of } \\
\text { uncertain affinity } 1 \text { ( } 3 \\
\mathrm{~mm} \text { ) }\end{array}$ \\
\hline NMW2012.36G.96 & $2(7 \mathrm{~mm})$ & $4(2 \mathrm{~mm})$ & $>10(0.5 \mathrm{~mm})$ & \\
\hline NMW2012.36G.97 & & $\sim 15(1 \mathrm{~mm})$ & $2(0.25 \mathrm{~mm})$ & \\
\hline NMW2012.36G.98 & & $15(5 \mathrm{~mm})$ & $3(0.5 \mathrm{~mm})$ & $\begin{array}{l}\text { Small echinoderm of } \\
\text { uncertain affinity } 2 \text { (1 } \\
\mathrm{mm})\end{array}$ \\
\hline NMW2012.36G.99 & & $13(8 \mathrm{~mm})$ & $9(0.5 \mathrm{~mm})$ & \\
\hline NMW2012.36G.101 & & $3(4 \mathrm{~mm})$ & $\begin{array}{l}\sim 6 \text { articulated } \\
\text { fragments }(1 \mathrm{~mm})\end{array}$ & \\
\hline NMW2012.36G.102 & & $\sim 30(1 \mathrm{~mm})$ & $\sim 15(0.75 \mathrm{~mm})$ & \\
\hline NMW2012.36G.103 & & $6(0.5 \mathrm{~mm})$ & $5(0.5 \mathrm{~mm})$ & $\begin{array}{l}\text { Trilobite } 1 \\
\text { (articulated, } 1 \mathrm{~mm}) \\
\text { Tergomyan } 1(1 \mathrm{~mm})\end{array}$ \\
\hline
\end{tabular}

